\title{
Akses Informasi Literasi Keislaman Rohis di Indonesia: Analisis Konstruksi Keberagamaan
}

\section{Access to Islamic Literacy Information of Islamic Spiritual (ROHIS) in Indonesia: Analysis of Religious Construction}

\author{
Muhammad Dalimunthe ${ }^{1)}$ \& Franindya Purwaningtyas ${ }^{2)}$ \\ 1) Fakultas Ilmu Sosial, Universitas Islam Negeri Sumatera Utara, Indonesia \\ 2) Program Studi Ilmu Perpustakaan, Universitas Islam Negeri Sumatera Utara, Indonesia
}

Diterima: 29 Februari 2020; Disetujui: 10 Juni 2020; Dipublish: 01 Juli 2020

\begin{abstract}
Abstrak
Penelitian ini dilaksanakan di tiga kota besar di Indonesia, yaitu Medan, Yogyakarta dan Makassar. Pemilihan lokasi ini didasarkan atas representasi SMA di Indonesia. Ketiga kota memiliki karakteristik Rohis yang berbeda dari kota lain. Penelitian ini bertujuan melihat akses informasi literasi keislaman di kalangan aktivis Rohis di Indonesia. Rohis menjadi pilar penting dalam membentuk model keislaman di sekolah umum, karena dianggap sebagai referensi Islam di sekolah. Model penelitian yang digunakan adalah kualitatif, dengan melakukan penggalian data yang mendalam melalui sudut pandang informan. Hasil penelitian menunjukkan bahwa dari tiga kota yang menjadi sampel memiliki karakteristik akses informasi keislaman yang berbeda. Kota Medan dan Makassar lebih didominasi oleh sosial media seperti Instagram dan YouTube. Selain itu, Makassar memiliki tokoh lokal populer yang menjadi sumber rujukan. Kota Yogyakarta lebih dominan dipengaruhi oleh lembaga pendidikan, organisasi keagamaan dan tokoh keagamaan lokal yang dapat diakses secara langsung. Model-model akses informasi mengkonstruksi keberagamaan Rohis dan pandangan mereka tentang negara dan orang yang berbeda, sehingga cenderung mengikuti model keberagamaan tokoh dan sumber informasi yang paling sering diakses dan dikonsumsi.

Kata Kunci: Akses Informasi Keislaman; Rohis; Konstruksi Keberagamaan; Islam di kelompok Millenial.
\end{abstract}

\section{Abstract}

This research was conducted in three major cities in Indonesia (Medan, Yogyakarta, and Makassar). The choice of location was based on the representation of high schools in Indonesia. These cities have different Rohis characteristics from other cities. This study aims to know access to Islamic information literacy among Rohis activists in Indonesia. Rohis became an important pillar in shaping the Islamic model in public schools because it was considered as a reference for Islam in schools. The research model used is qualitative, by analyzing in-depth data through the point of view of the informant through the FGD. The results showed that of the three cities sampled had different characteristics of Islamic information access. The cities of Medan and Makassar are more dominated by social media such as Instagram and Youtube. Also, Makassar has a popular local figure who is a source of reference. The city of Yogyakarta is more dominantly influenced by educational institutions, religious organizations, and local religious leaders that can be accessed directly. Models of access to information construct Rohis religious diversity and their views of different countries and people so that they tend to follow the religious model of the figures and sources of information that are most often accessed and consumed.

Keywords: Islamic Information access; Islamic Spiritual (ROHIS); Religious Construction; Islam in Millennial Groups.

How to Cite: Dalimunthe, M. \& Purwaningtyas, F. (2020) Akses Informasi Literasi Keislaman Rohis di Indonesia: Analisis Konstruksi Keberagamaan. PERSPEKTIF, 9(2): 378-387

*Corresponding author:

E-mail: muhammaddalimunte@uinsu.ac.id
ISSN 2085-0328 (Print)

ISSN 2684-9305(Online) 


\section{PENDAHULUAN}

Perkembangan teknologi menjadikan masyarakat dipenuhi dengan berbagai arus informasi. Semua tersaji secara instan lewat internet, pesebaran mobilitas media sosial, seperti Facebook, WhatsApp dan lainnya menjadikan keragaman informasi semakin kompleks. Dunia informasi yang diidentikkan dengan masyarakat urban (perkotaan) dan anak remaja, karena kalangan ini adalah pengguna informasi terbesar. Pesebaran informasi yang masif juga terjadi dalam bidang keagamaan, informasi seputar agama melimpah ruah di berbagai media, baik cetak maupun elektronik. Lagi-lagi pihak yang paling memiliki peluang dalam mengkases berbagai informasi tersebut didominasi oleh anak remaja.

Terkait akses informasi keagamaan, menjadi penting untuk melihat, memetakan serta menganalisis bagaimana Rohis (Rohani Islam) sekolah umum di kota besar dengan mobilitas tinggi dalam mengakses informasi keagamaan. Aktivis Rohis menjadi pilar penting dalam pergerakan komunitas keagamaan pada tingkat remaja di sekolah-sekolah SMA. Akses informasi keagamaan ini meliputi sumber informasi, cara mendapatkan informasi dan proses internalisasi nilainya dalam kehidupan sehari-hari yang kemudian membentuk persepsi keagamaan di kalangan aktivitas Rohis. Sebut saja misalnya persepsi tentang pola hubungan dengan teman yang berbeda agama, pemahaman tentang toleransi, makna jihad, terorisme, syariat Islam, nasionalisme, khilafah, demokrasi serta konsep nation state (negara bangsa) (Anwar, 1995).

Atas dasar gambaran singkat di atas, menjadi penting untuk melihat semua itu dalam satu kerangka kerja penelitian interdisipliner, yakni Ilmu Perpustakaan dan Ilmu-Ilmu Sosial. Ilmu Perpustakaan akan menganalisis terkait akses informasi keagamaan, sementara ilmu sosial akan menganalisis persepsi yang dihasilkan dari proses internalisasi informasi yang didapatkan oleh para aktivis Rohis.

Beberapa studi yang pernah dilakukan diberbagai wilayah di Indonesia seperti kajian yang dilakukan oleh Lembaga Kajian Islam dan Perdamaian (LaKIP), Setara Institute menunjukkan bahwa anak remaja di SMA memiliki akses informasi keagamaan yang beragam, khususnya terkait kecenderungan dalam memilih paham keagamaan. Penelitian yang dilakukan oleh Lembaga Kajian Islam dan Perdamaian (LaKIP) tahun 2011 di kalangan anak-anak SMA di Jakarta, Bogor, Depok, Tangerang, dan Bekasi (Jabodetabek) menunjukkan sekitar 50 persen responden setuju tindakan radikal atas nama agama (Kailani, 2011).

Kajian ACDP (Analytical and Capacity Development Partnership) dan Kementerian Agama tahun 2015 menyimpulkan bahwa: 1) Pengaruh radikalisme Islam masuk ke sekolah melalui kegiatan ekstrakurikuler dengan cara: a) Memanfaatkan kegiatan Rohis untuk menyebarkan faham radikal lewat mentor dan guru, serta menyediakan tempat kegiatan; b) Mengembangkan jaringan dengan alumni melalui kegiatan Rohis ketika mereka masih bersekolah di SMP dan SMA; c) Mengemas materi pelajaran agama Islam dalam bentuk pelatihan atau bimbingan belajar gratis. Modus ini sangat menarik bagi siswa terutama pada saat mereka sedang menghadapi ujian akhir atau ujian nasional; d) Memakai pendekatan edukasi seperti review buku, seminar, diskusi, dan kegiatan semi akademis yang lain di sekolah, masjid, atau tempat lain, yang terinspirasi dari pustaka tentang Islam puritan; dan e) Dikaitkan pelajaran agama Islam dengan kehidupan sosial remaja, termasuk tentang adab pertemanan (Aidulsyah, Wibisono, \& Adi, 2017).

Untuk menguji beberapa kesimpulan penelitian di atas, kajian tentang Rohis di SMA umum kota besar yang merupakan Indonesia bagian barat hingga timur yakni 
Medan, Yogyakarta dan Makassar menjadi menarik, hal ini dikarenakan kebanyakan penelitian yang sudah dilakukan dominan dengan pendekatan penelitian kuantitatif, yang hasilnya cenderung general. Penelitian akses informasi dan persepsi keagamaan Rohis SMA umum di Kota Medan, Yogyakarta dan Makasar adalah bagian dari upaya melengkapi data-data dari penelitian sebelumnya dengan cakupan yang lebih luas. Dan tentu uraian di atas menjadi latarbelakang kenapa penelitian ini menjadi penting, yakni upaya menganalisis berbasis kualitatif karena menggabungkan dua paradigma ilmu, yakni ilmu perpustakaan dan ilmu-ilmu sosial.

\section{METODE PENELITIAN}

Pengumpulan data dalam penelitian ini akan dilakukan dengan; 1) FGD (Focus Group Disscussion), yang merupakan kegiatan wawancara dengan sekelompok orang berdiskusi tentang suatu fokus masalah atau topik tertentu untuk melihat persepsi antar individu; 2) Observasi secara langsung pada kegiatan Rohis yang dilakukan oleh siswa SMA terkait dengan pendidikan keagamaan, persepsi keagamaan dan pola akses informasi keagamaan; 3) Dokumentasi, yang mana peneliti mengumpulkan data mengenai kegiatan Rohis terkait dengan akses informasi dan sumber apa yang digunakan untuk memenuhi kebutuhan informasi keagamaan. Hal ini dilakukan untuk membantu peneliti menganalisa persepsi, konten keagamaan dan perilaku akses informasi anggota Rohis SMA.

Pengambilan data dilakukan di tiga kota yaitu Medan, Yogyakarta dan Makassar. Rohis dari masing-masing kota diwakili oleh Rohis dari SMA berdasarkan tingkat keaktifan Rohis. Dari setiap kota sejumlah 17 sekolah yang diundang untuk mengambilan data lapangan (Medan: SMA Tritech, SMA Telkom, SMAN 6, SMAN 4, SMAN 11, SMA Budi Agung; Yogyakarta: SMA PIRI 1, MA Al-Qodir, SMA 1 Sleman,
SMAN 1 Cangkringan, SMAN 3 Yogyakarta, SMA IT Abu Bakar, SMAN 3 Bantul; Makassar: SMAN 5, SMAN 10, SMAN 11, SMAN 12).

\section{HASIL DAN PEMBAHASAN}

Rohis pada setiap sekolah memiliki kecenderungan dan ciri dalam menunjukkan eksistensinya dengan tetap menjadi wadah bagi pengembangan keislaman dalam diri siswa sebagai esensinya. Ragam kegiatan dilaksanakan sebagai bentuk perayaan maupun proses aktualisasi diri dari Rohis misalkan saja, PHBI yang rutin dilaksanakan sebagai bentuk program kerja Rohis. Bukan hanya itu, Rohis juga kerap melaksanakan kegiatan seperti mentoring dan liqo yang tak jarang melibatkan masyarakat. Dimana konteks masyarakat seperti alumni sekolah tersebut dan ulama serta beberapa public figure yang mampu menjadi motivator untuk membentuk karakter Islami siswa (Aidulsyah et al., 2017; Habibullah, 2014; Kailani, 2011; Shodiq, 2014; Yani, 2017).

Rohis di Medan memiliki karakter unik yang tidak merujuk pada basis tertentu dalam membangun eksistensi mereka. Rohis di kota Medan bertujuan membangun identitas diri dari Islam sendiri. Hal ini ditandai dengan munculnya kegiatan-kegiatan yang bernuansa Islam, seperti halnya PHBI dengan mendatangkan tokoh-tokoh Islam seperti ustad dan ustazah untuk membangun nilai-nilai kebaikan yang tidak berbatas pada ibadah kepada Tuhan semata namun juga segala sesuatu yang berkaitan dengan kehidupan sosial siswa dan siswi di sekolah.

Hasil FGD yang dilakukan Rohis di kota Medan memperlihatkan bahwa Rohis berperan membangun citra bahwa Islam mampu menyelesaikan segala permasalahan yang ada di kawasan sekolah, Rohis berperan sebagai wadah pengembangan diri, pembentukan karakter dan juga Rohis sebagai 
kampanyenya Islam di sekolah. Dengan demikian Rohis pada sekolah umum memiliki peran penting dalam proses pengembangan agama Islam di sekolah tersebut. Kegiatan Rohis ini merujuk pada sebuah jawaban atas kegelisahan atau fenomena yang terjadi di sekolah umum. Pada sekolah umum yang hanya memiliki waktu relatif sangat singkat dalam proses pendidikan karakter anak yang berbasis Islam sehingga dengan adanya Rohis diharapkan dapat menjadi opsi selanjutnya yang membantu dalam proses pembentukan karakter anak itu sendiri.

Rohis di Makassar memiliki karakter yang unik, meskipun memiliki tipologi kemiripan dengan berbagai Rohis yang ada di berbagai kota di Indonesia. Keunikan tersebut terletak pada kemampuan kelompok ini mengorganisir kelompoknya kedalam asosiasi yang lebih besar dari cakupan sekolah. kemampuan mereka membangun asosiasi ini tidak hanya karena jejaring alumni Rohis yang tergabung ke dalam organisasi sayap partai seperti pada umumnya di beberapa kota, melainkan watak dari masyarakat Bugis dalam sejarahnya memang kuat dalam membangun jejaring asosiasi berbasis agama.

Berdasarkan observasi dan proses pengambilan data lapangan, dan argumenargumen yang disampaikan oleh aktivis Rohis terdapat karakteristik yang berbeda antara satu sekolah dengan sekolah yang lain. Perbedaan ini disebabkan karena proses pembinaan yang dilakukan oleh alumni sebagai tulang punggung pengkaderan memiliki karakter dan pandangan yang berbeda. Sebut saja misalnya pandangan konsep Islam tentang negara, ada perbedaan yang cukup mendasar, ada yang setuju dengan formalisasi syariat Islam ada yang tidak setuju dengan formalisasi syariat Islam di Kota Makassar.

Penyebab lain mengapa terjadi perbedaan karakter, anak-anak yang aktif di Rohis berlatarbelakang keagamaan yang berbeda, guru agama yang berbeda ketika di rumah dan di sekolah sebelumnya. Pandangan guru agama yang mengajar di sekolah juga turut membentuk bagaimana karakteristik Rohis. Guru agama menjadi bagian dari dewan pembina, meskipun tidak sekuat alumni yang mengkader, pandangan-pandangan keagamaan turut serta memberikan corak bagi para aktivis Rohis. Di Makassar menempati posisi yang cukup dihormati dan disegani, apalagi guru agama Islam posisinya berbeda dengan guru non agama lainnya (Petikan FGD oleh Imam Muhajirin, 2019).

Analisis data lapangan dari perspektif pembacaan analisis peta paradigma ideologi misalnya, ternyata menunjukkan hasil yang tidak tunggal, dengan kata lain memiliki ragam paradigma, di antaranya seperti paradigma revivalist, paradigma modernis, dan paradigma transformatif. Hal ini senada dengan riset yang pernah dilakukan oleh Fachri Aidulsyah dkk, di kota Solo (Aidulsyah et al., 2017). Paradigma tersebut merupakan model atau karakter Rohis. Ketiga paradigma ini memiliki bentuk dan cirinya masingmasing dan setiap orang dalam satu organisasi memiliki paradigma ideologinya masing-masing dalam menjalankan kehidupan beragama termasuk dalam agama Islam. Yang menarik adalah, berdasarkan hasil riset tentang dinamika Rohis yang di lakukan di beberapa SMA di Eks Se-Karesidenan Surakarta menunjukkan kecenderungan yang sangat menarik dalam menjawab tantangan globalisasi itu sendiri (Aidulsyah, Wibisono, \& Adi, 2013).

Sementara itu, Aktivis Rohis di sekolah umum kota Makassar, memiliki kecenderungan paradigma yang hampir sama. Dalam satu sekolah di antara aktivis Rohis pun terdapat perbedaan, misalnya paradigma revivalist (Azra, 1996). Dalam pandangan yang diyakini oleh aktivis Rohis di kota Makassar, Islam harus kembali pada kemurnian. Bagi kelompok ini, Islam akan mengalami kejayaan dan 
kemajuan sebagaimana Islam yang dijalankan pada masa nabi Muhammad.

Jika dicermati paradigma revivalisme

ini dilatarbelakangi atas gencarnya gerakan Tarbiyah yang masuk ke dalam lini pendidikan. Jejaring Tarbiyah dan aktivis Rohis menjalin hubungan dengan para aktor-aktor atau tokoh agama pada level nasional seperti nama-nama besar ustad digital, sebut saja Ustad Basalamah, Firanda dan kelompok yang sepaham dengan gerakan revivalist.

Di Makassar ada nama seorang tokoh yang cukup terkenal, ia dikagumi oleh kalangan anak-anak muda muslim, ceramahnya selalu penuh oleh anak-anak muda, bahkan akun sosial medianya pun memiliki jumlah pengikut terbanyak untuk tokoh agama di kawasan Makassar. Nama tokoh tersebut adalah Ustad Muh. Fakhrurrazi Anshar, ia dijuluki sebagai ustad millenial.

Paradigma modernis kalangan aktivis Rohis ditandai dengan ragam ekspresi apa yang mereka sebut dengan budaya Islam bernuansa populer seperti musik religius dan acara-acara dengan nuansa modern berbungkus religiusitas. Kalangan ini adalah mereka yang memiliki paham untuk tidak terlalu mempermasalahkan adanya pengaruh budaya global dalam dinamika dakwah yang mereka sajikan. Istilah 'Islam modernis' merupakan proyek dari generasi Islam baru yang terpengaruh Barat untuk menyesuaikan diri dengan peradaban modern, namun dengan tetap mempertahankan kesetiaan terhadap kebudayaan Islam. Dengan kata lain, modernisme Islam merupakan sebuah titik tengah (interstitial space) antara Islamisme dan sekularisme, yang mungkin saja akan bergerak kembali ke arah Islamisme atau bergerak ke arah sekulerisme seperti halnya yang terjadi di Turki di bawah Turki Muda, atau tetap berada dalam posisi moderat di antara kedua titik ekstrem itu (Latif, 2012). Dalam Oxford English Dictionary dijelaskan bahwa yang menjadi isu sentral adalah mengupayakan agar keyakinan agama serasi dengan pemikiran modern (Latif, 2012).

Paradigma modernis di kalangan aktivis Rohis Makassar memang tidak dominan, kalau dipetakan dari 7 sekolah yang menjadi sampel pengambilan data primer cenderung terlihat paradigma revivalist lebih dominan, pada sesi Focus Group Discussion terlihat bahwa paradigma pemikiran keagamaan mereka lebih dekat dengan paradigma revivalist.

Jejaring gerakan revivalisme Islam di kota Makassar menemukan momentumnya pada gerakan Islam pasca Orde Baru, selain tentu sejarah Islam yang kuat. Pada level jejaring di lembaga pendidikan, munculnya sekolah Islam terpadu turut serta menjadi bagian dalam penguatan ideologi revivalisme. Di sekolah umum mereka memanfaatkan jejaring aktivis Rohis, di kampus mereka masuk melalui jalur Lembaga Dakwah Kampus, pada level organisasi masyarakat, mereka ikut serta dalam gerakan politik dan lembaga keagamaan.

\section{Akses Informasi Keagamaan Rohis}

Memahami akses informasi terlebih dahulu memahami kebutuhan seseorang terhadap informasi, masyarakat global yang konsumtif terhadap informasi. Antara want dan need yang saling terkait, di mana kebutuhan muncul dari keinginan yang kuat akan sesuatu (Pendit, 2017). Katakan saja informasi, konteks masyarakat informasi yang menjadi produsen, distributor, manipulator dan konsumen informasi menjadi dampak globalisasi. Ditambah lagi masyarakat informasi memunculkan masyarakat cyber, di mana hampir setengah kebutuhannya akan informasi terpenuhi melalui konektivitas. Kebutuhan menurut Wilson bahwa kebutuhan dibagi ke dalam tiga kategori yaitu: 1) Physiological needs, merupakan kebutuhan dasar yang harus dipenuhi untuk mempertahankan kehidupan fisik seperti makan dan minum; 2) Affective 
needs, merupakan kebutuhan fisiologis atau kebutuhan berdasarkan emosi manusia seperti cita-cita; 3) Cognitive needs, merupakan kebutuhan yang muncul dari keinginan diri untuk mengetahui sesuatu seperti kebutuhan akan informasi (Nurudin, 2009).

Peran media sebagai media informasi, yaitu media yang setiap saat menyampaikan informasi kepada masyarakat. New media merupakan media yang menawarkan digitisation, convergence, interactivity dan development of network terkait pembuatan pesan dan penyampaian pesan atau informasi. Kemampuanya menawarkan interaktivitas ini memungkinkan pengguna dari New Media memiliki pilihan informasi apa yang dikonsumsi, sekaligus mengendalikan keluaran informasi yang dihasilkan serta melakukan pilihan-pilihan yang diinginkannya. Kemampuan menawarkan interaktifitas inilah merupakan konsep sentral dari pemahaman tentang New Media (Watie, 2016). New Media yang terkait dengan komunikasi masa mengandalkan media massa, memiliki fungsi utama, yaitu menjadi proses penyampaian informasi kepada masyarakat luas. Komunikasi massa memungkinkan informasi dari institusi publik tersampaikan kepada masyarakat secara luas dalam waktu cepat, sehingga fungsi informative tercapai dalam waktu singkat dan cepat (Jinan, 2012).

New Media yang mengandalkan jejaring berbeda dengan media lama berupa televisi, radio dan surat kabar. Terlihat dari interaktivitas dari media yang saling terintegrasi dan terkoneksi dengan jaringan menghubungkan banyak pihak ke global yang maya atau virtual. Bukan hal yang tabu lagi ketika seseorang berekspresi pada sesuatu yang tak berwujud hanya dengan melihat perangkat pintar. Di sini orang tak perlu lagi melihat, bertemu dan merasakan secara langsung, hanya dengan melihat secara virtual keterlibatan seluruh indera menjadi nyata (Rubawati, 2018).

Munculnya dunia virtual sebagai bentuk kehidupan baru, manusia saling berinteraksi walau tak saling mengenal dan bertemu secara langsung. Berbagi informasi bahkan data pribadi melalui media sosial bahkan menggiring masyarakat kearah global yang ditandai dengan 'akhir sosial' sebagai akibat modernisasi. Akhir sosial juga ditandai oleh transparasi sosial, yaitu satu kondisi lenyapnya kategori sosial, batas sosial, hierarki sosial yang sebelumnya membentuk suatu masyarakat. Jaringan informasi menjadi bersifat transparan dan virtual tatkala tak ada lagi kategorikategori moral yang mengikatnya dan ukuran-ukuran nilai yang membatasinya. Party-line merupakan gambaran masyarakat cyber kita yang tenggelam di dalam ekstasi komunikasi. Orang yang terbuai dalam komunikasi di dalam dunia cyber bisa tenggelam di dalamnya dan terbawa arus gaya komunikasi yang ada, hingga tak jarang bisa seolah menjadi sosok lain, yang jauh beda dengan dunia nyatanya (Piliang, 2013).

Lahirnya teknologi informasi berimbas pada munculnya tantangan bagi aktivis dakwah Islam di Indonesia untuk merubah pola dakwahnya yang bersifat konvensional kepada dakwah yang berbasis teknologi informasi atau mengkombinasikan antara dakwah konvensional dengan dakwah berbasis teknologi informasi (Daulay, 2001). Hasilnya, berbagai ormas Islam pun tidak ketinggalan untuk menciptakan situs-situs resmi atau bahkan media-media sosial sebagai sarana menyampaikan dakwah, demi menjawab tantangan tersebut. beberapa ormas yang dimaksud antara lain; Nahdlatul Ulama, Muhammadiyah, Persis, dan Front Pembela Islam. Begitu pula dengan organisasi-organisasi Islam lainnya (Hidayat, 2012).

Tantangan pada zaman modern adalah tantangan menghadapi budaya 
masyarakat modern yang sangat bergantung kepada teknologi. Menjawab tantangan itu, Islam harus membuat strategi dakwah yang berbasis pada pemanfaatan teknologi modern. Seperti pemanfaatan jejaring sosial (social network), website, aplikasi-aplikasi mobile, dan sebagainya. Termasuk menggunakan strategi e-paper yang saat-saat ini sedang digandrungi oleh masyarakat luas. Pasalnya selain ramah lingkungan, e-paper dirasa lebih praktis dan efisien, khususnya dalam pemanfaatan ruang dan meniadakan penggunaan bahan baku kertas sebagai bahan dasarnya (Slamet, 2013).

Banyak siswa yang sekarang sudah mengetahui berbagai informasi keislaman. Karena sekarang sudah banyaknya media yang dapat membantu dalam berbagai hal, mulai dari media sosial WhatsApp, Instagram, Facebook, dan lain sebagainya. Mereka dapat mengakses informasi tersebut karena mudah untuk dilakukan. Apalagi dengan adanya YouTube dapat membantu dalam memahami dakwah yang dilakukan oleh beberapa da'i yang sudah menggunakan media sosial sebagai media dakwahnya (Jinan, 2012; Rubawati, 2018).

Peran orang tua, guru agama, mentor sangat berpengaruh bagi proses konvensional anak. Proses akses sering dua arah, direct dan terbatas pada ruang dan waktu tertentu. Pengajian di lingkungan rumah, sekolah dan kegiatan keislaman di sekitar kota Makassar. Pada media digital, media sosial paling dominan Instagram, YouTube: Ustad Basalamah, Zakir Naik, Abdul Somad, Fakhrurrazi (Tokoh Lokal) Firanda dan lain sebagainya. Akses satu arah, sumber informasi melimpah ruah, proses penyaringan individual, bebas memilih suka atau tidak tanpa ketergantungan kultural. Selain itu tokoh publik dengan follower terbanyak di Instagram seperti Ustad Yusor Ansor atau Salim A. Fillah, Ustad Khalid Basalamah, menjadi akun yang paling diminati.
Secara peta konsep terkait model akses informasi keislaman dapat dijelaskan dalam bagan di bawah ini:

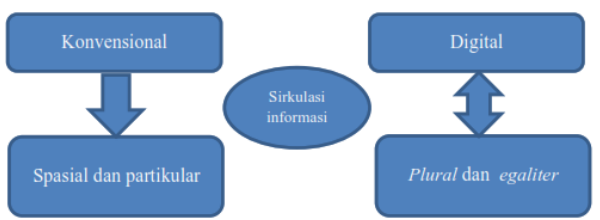

Gambar 1. Peta Konsep Akses Informasi Keislaman

Era global sarat aksen digital sebagai instrumen penting dalam segenap aspek kehidupan. Berfungsi sebagai sarana yang dapat meringankan berbagai beban aktivitas yang dilakukan oleh manusia. Digital di era global yang didukung komunikasi tanpa batas, akan menghadirkan dua formasi wajah. Satu sisi dapat bermanfaat bagi manusia dalam berbagai tatanan berbagai aspek kehidupan. Sisi lain dapat menyalahi kodrat manusia sebagai makhluk ciptaanNya, apabila pemanfaatan media digital itu tidak mengindahkan norma-norma agama dan nilai-nilai individual, universal, kolektif, juga kearifan lokal, dan tradisional yang dikelola dengan manajemen yang baik.

Era global dengan orbitnya instrument digital sebagai alat yang dapat memberikan apa saja, juga dapat mempermudah dan mempercepat keinginan dalam banyak aspek kehidupan, baik yang positif maupun negatif. Fakta menunjukkan bahwa instrumen digital berperan langsung dalam setiap aspek kehidupan. Hadir dalam berbagai penawaran untuk kemudahan dan kepentingan penguatan norma-norma, nilai-nilai, sehingga tujuan dari suatu pembelajaran yang bersifat normatif dan transformasi nilai-nilai lainnya berlabuh pada tujuan yang direncanakan. Misalnya semakin kuatnya pemahaman normanorma, nilai-nilai keagamaan, dan kemasyarakatan yang dapat menuntun individu pada hidayah, jalan yang lurus, 
baik dalam aspek-aspek teologis, humaniora, dan kesemestaan dengan memanfaatkan instrumen digital yang semakin mudah didapatkan (Yusup \& Subekti, 2010).

Hal ini juga menjadi bentuk kekhawatiran dari masing-masing sekolah dan guru terhadap siswa dan siswi yang memiliki rutinitas aktif dengan media sosial, bahwa setiap anak mudah goyah dan terkontaminasi dengan berbagai informasi yang dimuat di media sosial tanpa filter (Jinan, 2012; Yani, 2017). Seperti halnya yang beredar di sekolah, sering kali siswa dan siswi mengangkat tema yang sedang hangat diperbincangkan di media sosial sebagai bahan diskusi pada kegiatan Rohis di sekolah, hal ini tidak serta merta menjadikan media sosial sebagai sarana yang bersifat negatif namun malah sebaliknya yakni memberikan efek positif kepada siswasiswi yang menjadikan media sosial sebagai bahan rujukan dalam mencari informasi yang berbasis keislaman (Candra, 2012; Kailani, 2011).

Media yang sering digunakan di sini seperti halnya Instagram, bagi siswa dan siswi mengikuti akun dari ulama tertentu untuk mendapatkan informasi yang mereka butuhkan, yakni informasi yang dikemas dalam bentuk ceramah oleh berbagai tokoh agama yang ada di Indonesia. Tokoh agama tersebut tentunya yang dijadikan sebagai pedoman dalam pengambilan keputusan untuk berbagai ketentuan hukum dalam Islam.

Tokoh ulama tersebut menggambarkan bahwa siswa-siswi SMA ini sangat aktif dalam bermedia sosial untuk memperoleh informasi keislaman yang mereka butuhkan, umumnya dari masing-masing ulama yang disebutkan di atas adalah ulama yang gaya penyampaiannya menyesuaikan dengan pola pikir anak muda zaman sekarang. Seperti halnya Ustad Abdul Somad yang mengemas ceramahnya dengan lebih santai agar mudah dipahami oleh seluruh kalangan, begitu pula dengan Ustad Adi Hidayat yang memiliki karakter lebih terstruktur dalam proses penyampaiannya sehingga setiap orang lebih mudah memahami dan mengkonsep informasi yang disampaikan.

Selanjutnya Ustad Hanan Attaqi yang mulai dari gaya berpakaian, cara penyampaian hingga pada materi yang disampaikan memang disesuaikan dengan anak remaja, sehingga ada rasa kecocokan di antara keduanya dan tentunya anak remaja merasa apa yang disampaikan sesuai dengan kondisi yang sedang mereka alami. Berusaha memahami remaja dengan lebih santai ala anak muda (youth generation) berhasil menarik perhatian remaja. Mengambil konteks yang sedang viral dengan mengemas informasi menggunakan Bahasa dan kalimat 'anak gaul' menjadi hal disukai remaja, sehingga menjadi contoh bagi remaja bahwa Islam juga 'tidak kuno', Islam modernitas.

Sama dengan hal di atas beberapa konten menarik yang sangat remaja ingin ketahui adalah menyangkut kehidupan pribadi remaja. Tak luput soal asmara sering kali menjadi perhatian utama, ditambah lagi beberapa remaja yang tertarik dengan isu politik.

Metode yang paling akrab dengan siswa Rohis adalah dakwah dalam bentuk konvensional misalkan saja pada hari tertentu diadakan kegiatan mentoring yang mengundang alumni dan tokoh agama yang dianggap memiliki pengaruh terhadap anak muda (millennial). Dakwah lainnya dalam konten digital yang dapat diakses kapan saja dan di mana saja tanpa batasan ruang dan waktu. Kemudahan melihat dakwah digital dengan mengikuti akun Instagram beberapa pendakwah digital dan juga akun yang memberikan konten hijrah kepada remaja penggunaan media sosial berbasiskan konten juga sering menjadi alat yang digunakan untuk mencari pemahaman tentang Islam yaitu YouTube. Beberapa di antaranya dakwah ustad Zakir Naik yang menarik perhatian 
remaja bahkan kalangan tua karena dianggap lugas, tegas dan berani dalam menyampaikan keislaman.

\section{SIMPULAN}

Rohis di SMA Umum di 3 kota besar di Indonesia yaitu Medan, Yogyakarta, dan Makasar dalam melakukan akses informasi keislaman. Rohis memiliki kecenderungan untuk melakukan pemenuhan kebutuhan informasi keislaman melalui beberapa akses secara konvensional dan digital. Dalam bentuk konvensional dengan keinginan untuk melakukan pemurnian kembali pemahamn keislaman (revivalist). Semangat revivalist tersebut mereka wujudkan dalam berbagai bentuk kegiatan kerohanian di dalam lingkungan sekolah, antara lain melakukan mentoring dan seminar dengan melibatkan alumni yang merupakan generasi millennial.

Akses informasi melalui konten digital dengan penggunaan media sosial, salah satunya mengikuti akun Instagram dari tokoh muda dan popular dan melelaui akses YouTube. Khususnya makassar memiliki tokoh lokal yang menjadi salah satu cara siswa untuk mendapatkan informasi keislaman.

Melalui akses informasi keislaman yang dilakukan oleh siswa membentuk persepsi keislaman Rohis yaitu Persepsi keagamaan Rohis yang berkaitan dengan masalah-masalah sosial-kemasyarakatan terlihat para siswa responsip terhadap isuisu aktual di Indonesia.

\section{DAFTAR PUSTAKA}

Aidulsyah, F., Wibisono, N., \& Adi, Y. A. (2013). Kerohanian Islam (Rohis) dalam Jurang Globalisasi Aktivisme Rohis SMAN di Eks SeKaresidenan Surakarta (Solo Raya) dalam Menjawab Tantangan Zaman. Jurnal Pemikiran Sosiologi, 2(2).

Aidulsyah, F., Wibisono, N., \& Adi, Y. A. (2017). Kerohanian Islam (Rohis) dalam Jurang Globalisasi Aktivisme Rohis SMAN di Eks SeKaresidenan Surakarta (Solo Raya) dalam Menjawab Tantangan Zaman. Jurnal Pemikiran Sosiologi, 2(2), 25. Universitas Gadjah Mada.
Anwar, M. S. (1995). Pemikiran dan Aksi Islam Indonesia: Sebuah Kajian Politik tentang Cendikiawan Muslim Orde Baru. Jakarta: Paramadina.

Azra, A. (1996). Pergolakan Politik Islam: Dari Fundamentalisme, Modernime hingga PostModernisme (Cet. 1.). Jakarta: Paramadina.

Candra, A. (2012). Meng-alay dalam Dunia Maya: Disorder Bahasa dalam Cyberspace. Komunikator, 4(2), 93-102. Retrieved June 9, 2020,

from https://journal.umy.ac.id/index.php/jkm/ar ticle/view/194

Daulay, H. (2001). Dakwah di Tengah Persoalan Budaya dan Politik. Yogyakarta: LESTI.

Habibullah, A. (2014). Sikap Sosial Keagamaan Rohis di SMA Pada Delapan Kota di Indonesia. EDUKASI: Jurnal Penelitian Pendidikan Agama dan Keagamaan, 12(3). Retrieved August 5, 2019, from https://jurnaledukasikemenag.org/index.ph p/edukasi/article/view/95

Hidayat, D. (2012). Gerakan Dakwah Salafi di Indonesia: Studi tentang Kemunculan dan Perkembangannya di Era Reformasi. Universitas Indonesia.

Jinan, M. (2012). New Media dan Pergeseran Otoritas Keagamaan Islam di Indonesia. Jurnal Lektur Keagamaan, 10(1), 181-208. Retrieved August 5, 2019, from https://jurnallekturkeagamaan.kemenag.go.i d/index.php/lektur/article/view/178

Kailani, N. (2011). Kepanikan Moral dan Dakwah Islam Populer (Membaca Fenomena 'Rohis' di Indonesia). Analisis: Jurnal Studi Keislaman, 11(1), 1-16. Retrieved August 5, 2019, from http://ejournal.radenintan.ac.id/index.php/ analisis/article/view/604

Latif, Y. (2012). Inteligensia Muslim dan Kuasa Genealogi Inteligensia Muslim Indonesia Abad Ke-20. Jakarta: Democracy Project.

Nurudin. (2009). Pengantar Komunikasi Massa. Jakarta: Rajagrafindo Persada. Retrieved June 9, 2020, from http://www.rajagrafindo.co.id/produk/peng antar-komunikasi-massa/

Pendit, P. L. (2017). Perilaku Informasi, Semesta Pengetahuan. www.iperpin.wordpress.com. Retrieved June 9, 2020, from https://docplayer.info/34644009-Perilakuinformasi-semesta-pengetahuan.html

Piliang, Y. A. (2013). Masyarakat Informasi dan Teknologo (Teknologi Informasi dan Perubahan Sosial). Jurnal Sosioloteknologi, Jawan Barat: Institut Teknologi Bandung, 12(29), 143-156.

Rubawati, E. (2018). Media Baru: Tantangan dan Peluang Dakwah. Jurnal Studi Komunikasi 
(Indonesian Journal of Communications Studies), 2(1). Retrieved August 5, 2019, from

http://ejournal.unitomo.ac.id/index.php/jsk /article/view/586

Shodiq, S. F. (2014). Ideologi Pendidikan Islam pada Rohis di SMA N 2 Yogyakarta. Yogyakarta: UIN Sunan Kalijaga Yogyakarta.

Slamet. (2013). Dakwah Islam di Tengah Globalisasi Media dan Teknologi Informasi . Academia.edu. Retrieved June 9, 2020, from https://www.academia.edu/5526410/Dakw ah_Islam_di_Tengah_Globalisasi_Media_dan_ Teknologi_Informasi
Watie, E. D. S. (2016). Komunikasi dan Media Sosial (Communications and Social Media). Jurnal The Messenger, 3(2), 69. Universitas Semarang. Retrieved June 9, 2020, from http://journals.usm.ac.id/index.php/themessenger/article/view/270

Yani, Z. (2017). Bacaan Keagamaan Aktivis Rohis: Studi Kasus di SMA Negeri 3 dan 4 Kota Medan. Penamas, 27(1), 47-62.

Yusup, P. M., \& Subekti, P. (2010). Teori dan Praktik Penelusuran Informasi: Information Retrieval. Kencana Prenada Media Group. 